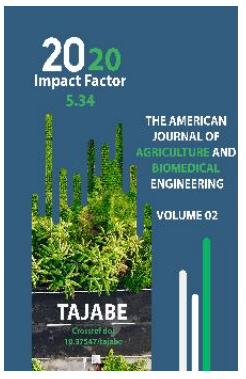

\section{Bioecology And Species Of Diaspididae In Fruit Gardens}

\author{
Jurabek Nodirjonovich Yakhyoyev \\ Junior Researcher, Institute Of Zoology Of The Academy Of Sciences Of The Republic Of \\ Uzbekistan
}

Khojimurod Khamrokulovich Kimsanbayev

Doctor Of Biological Sciences, Professor, Tashkent State Agrarian University, Uzbekistan

Copyright: Original

content from this work

may be used under the

terms of the creative

commons attributes

4.0 licence.

\title{
ABSTRACT
}

A dangerous pest is widespread in Uzbekistan. Of these is a dangerous coccid. They damage many plants. It damages the apple tree, pear, plum, quince, peach, almonds, hawthorn, elm, poplar and others. Winter diapausing larvae of the first age, covered with a dark gray or black shield. In the spring they are intensively fed, molt and form a shield similar to that of an adult female. After the second moult, adult females are formed. After mating, females spawn larvae-tramps, which creep along branches and leaves, and can also settle on fruits. They give rise to the next generation.

\section{KEYWORDS}

Orchard, population, adult, offspring, larvae, apples, cherries, plums, peaches, purple scale insect, comma scale.

\section{INTRODUCTION}

Today, special emphasis is placed on conducting research on the bioecology of orchard pests, which play an important role in the sustainable development of the agricultural complex and food security of the world's leading countries. In this place, especially in the orchards of the republic are pests for almost all species and are widespread Turan false shield (Rhodococcus turansis Arch.), Purple shield (Parlatoria oleae Colvee), Central Asian shield (Lepidosaphes mesasiatica Borch.), Plum shield Boris. ), 
acacia false shield (Parthenolcanium corn Bouche.), peach false shield (Parthenolcanium persicae F.), Asian shield (Neochionaspis asiatica Arch.), California shield (Quadraspidiotus perniciosus Comst.). These include quarantine species that are considered dangerous in the republic's horticulture, including the California shield. California shield, turon false shield, purple and Central Asian comma shield species, which are common every year and cause great damage to fruit, occupy a special place.

\section{LITERATURE REVIEW}

The fertilized female of the purple shield overwinters in its bark, under the shield of the forage plant. The minimum winter temperature affects the shield, wintering can withstand temperatures for a short time, even if $-11-15^{\circ} \mathrm{C}$. But when the temperature is $-29^{\circ} \mathrm{C}$, almost all of them die.

In the spring, with the onset of aphrodisiacs in forage plants, the females continue to feed. At the end of the flowering of the apple begins to lay eggs. In 2018, the first laid eggs were detected on April 24, with an average air temperature of $17,4^{\circ} \mathrm{C}$ and a relative humidity of $55 \%$. On April 30, 2019, the average ten-day temperature was $12,9^{\circ} \mathrm{C}$ and the relative humidity was $49 \%$. After 9 to 12 days, the larvae emerge from the eggs, are located on the leaf and fruit bands, and are less common on the leaf surface.

The first-year larvae appear in the first and second decade of May, May 6, 2018 - May 11, 2019 , when the average air temperature is 15,4 $-21,5^{\circ} \mathrm{C}$ and relative humidity $48-68 \%$.

The second-year larvae were identified on May 24 and 31, and it should be noted that the female larvae develop into adult females after the second ovulation, while the male larvae undergo successive pronymphatic and nymph phases after the second ovulation, and adult males begin to emerge. Female and male mature breeds were identified in late June and early July. The period of laying the first eggs of females was determined in the first ten days of July (July 8, 2018 - July 8, 2019).

The sexual productivity of females ranges from 20 to 50 to 70 eggs. The first larvae were detected in mid-July 2018 (16.07), and in 2018 at the end of the second decade of July (19.07), the emergence of larvae continues until early August (2.08). Representatives of the second generation significantly more than the first, the larvae clung to the leaf bands, veins, twigs and branches, fruit bands and fruits, and asked for juice. One month after the start of feeding, the larvae hatch a second time, and in late August, female and male imagoes appear. After mating, the males die. The females go to winter.

Thus, the purple shield gives twice the generation during the growing season. During the observation period, we found that in the second generation there are many breeds, which are located on the leaves and fruits, which requires us to conduct a special calculation. In these calculations, the ratio between the rocks of the purple flax is determined. To do this, 2 branches were cut from 5 affected trees, 12 leaves (4) and 12 fruits (4) were removed from each side of the tree and the shield of the shield was observed and counted. The color of the female is white or gray, the skin of the second young larva is eccentrically located at one edge of the shield and occupies one third of its area, the length of the shield is $2-2,5 \mathrm{~mm}$. The shield of the male shield is elongated, flat, with the skin of the first young larva, the length of the shield is $1,5 \mathrm{~mm}$. 


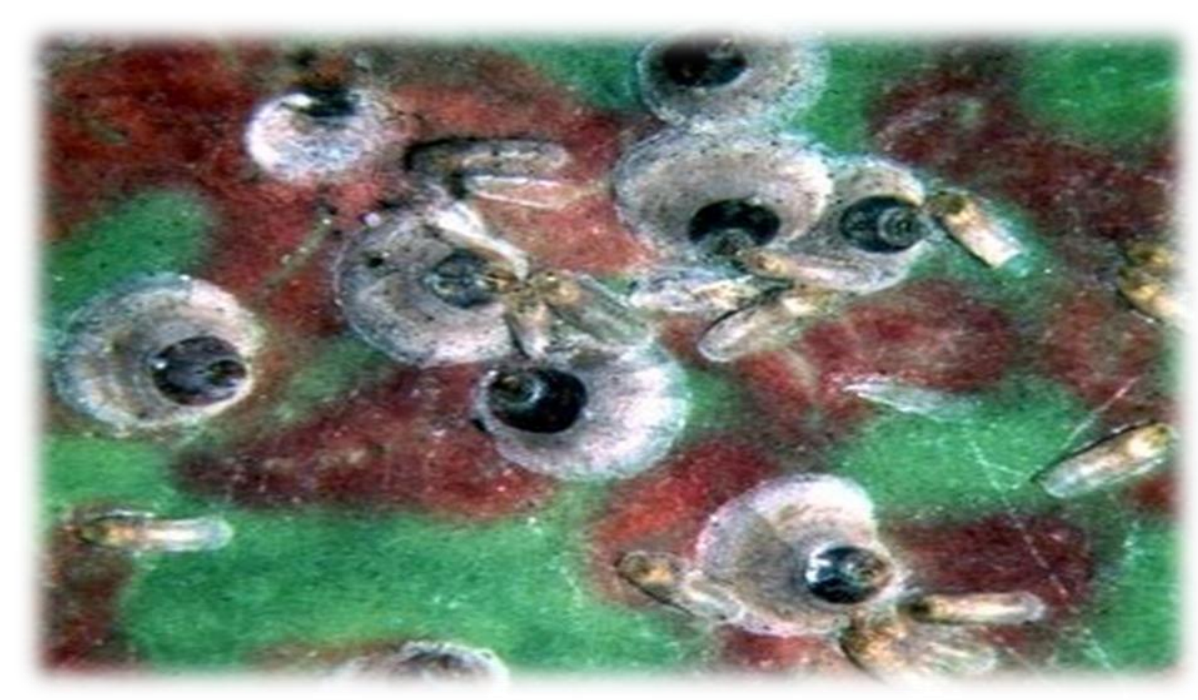

Figure 1. Purple shield (Parlatoria oleae Colvee).

Most researchers report that the purple shield also infects: barberry, hawthorn, oak, tobulga, pomegranate, olive, mulberry, laurel, mackerel, catalpa, padub, Semenov maple, white acorn, and yellow acacia. Of the 41 species of infected plants, 14 are fruit-berry plants, which are severely damaged by the purple shield. Especially affected apples, pears and partially apricots.

The first-year and partly second-year larvae and adult females of the California shield overwinter, but two-year-old larvae and adult females die in the winter. Shields overwinter under the branches and shields of trees. In late February, the dormant larva begins to move to the second year. But during the winter $20-50 \%$ of the larvae die. The ratio of males to females is on average the same. As the trees begin to turn green, the larvae begin to feed and, by shedding their bark 2 times, become sexually mature females and males.

It wakes up when the air temperature averages $+7,3^{\circ} \mathrm{C}$, and at $+10^{\circ} \mathrm{C}$ the second peeling begins, the peeling coincides with the emergence of the first buds of the apple. It takes 12 to 16 days from the start of feeding to the third peeling, and the third peeling lasts as long. During this time, the male shield begins to fly, and the female is sexually active. Male shields are very rare, lasting several hours. It dies after mating with the female. The emergence of female and male shields lasts from late April (early) to May 20 (late), depending on air temperature. It is very important to determine the time of emergence of male insects, so the pheromone traps should be placed at the most optimal time, because the male insects fly only a few days. 


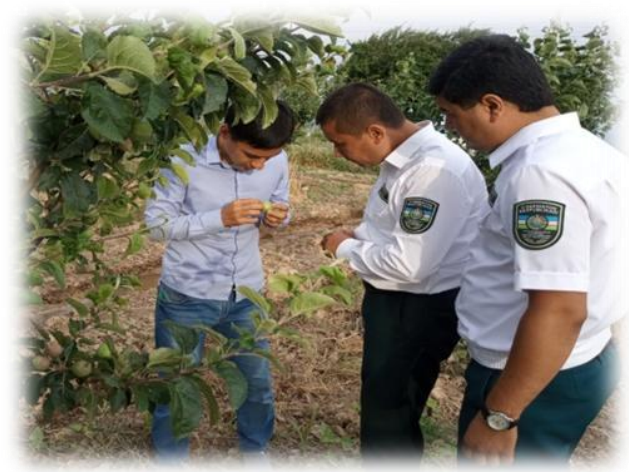

\section{Supervision with plant quarantine} inspectors

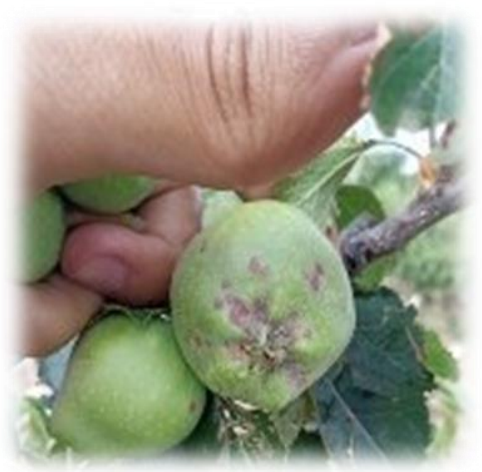

Damaged apple fruit

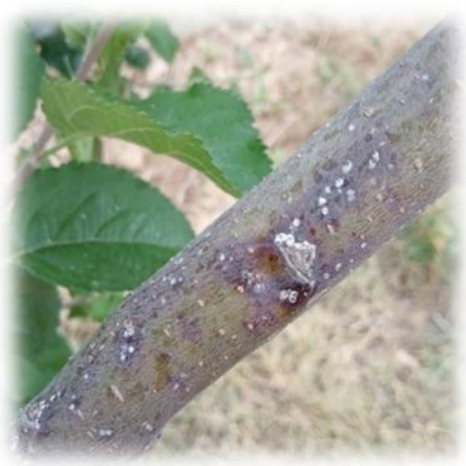

Damaged apple horn

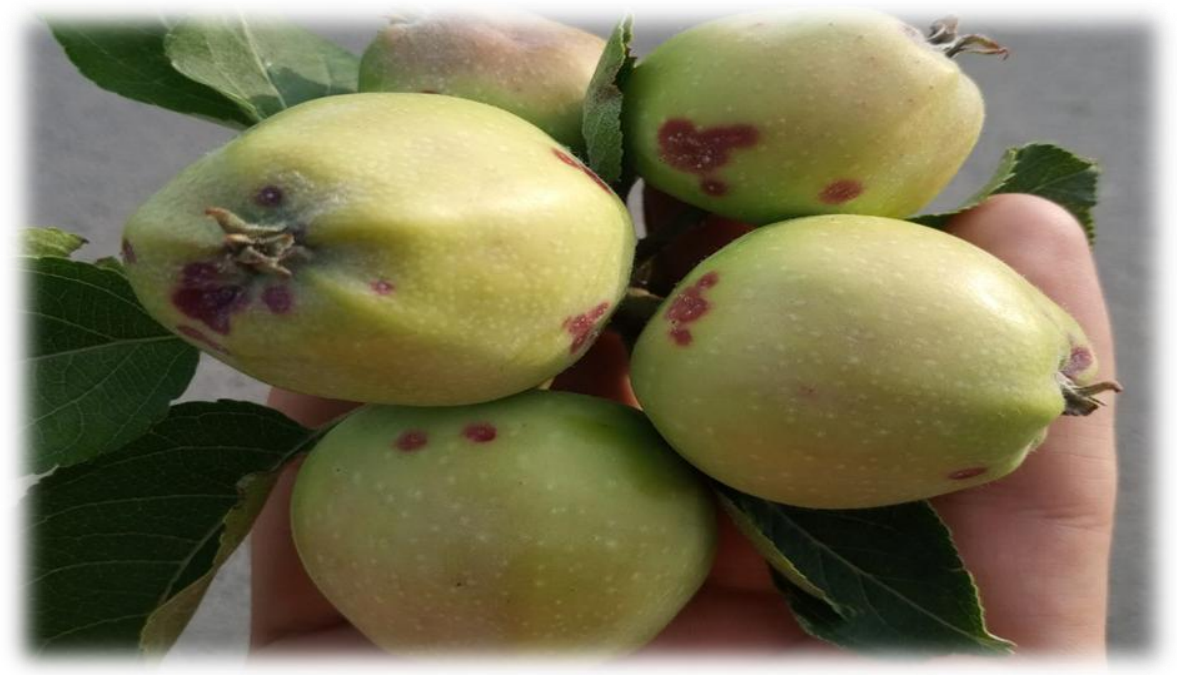

Figure 2. California shield (Quadraspidiotus perniciosus Comst.)

Sometimes the bulk of the male insects fly for two to three days. Female insects live for more than two and a half months. Once the ovaries of the female insect are fertilized, the egg cells develop. This process takes a month. The female of the California shield gives birth to 100-200 larvae (up to 500 in some places in the south). In Uzbekistan, the California shield produces 3-4 generations per season. Gives 4 generations in Tajikistan and Azerbaijan. Some of the larvae of each generation remain for the winter. Finally, the first young larvae of the last generation undergo special training and overwinter under the mother's shield. However, if conditions are available (plants in greenhouses and other homes), the California shield can thrive year-round. California shield can be propagated mainly in seedlings. Infected fruit also has the potential to spread through trade routes.

The body of the plum shield female is noxious or oval in shape, orange in color. There are no hairs on the top of the mustache and there are two tumors at the end. Pygidia with 2-3 pairs of broad fragments. The first pair is bitten on the inner edge, the fragments of the second and third pairs are divided into two, the crowns are hairy. The shield of the female is covered with hairy yellow or orange worm skins, which protrude from the head of the 
shield. the posterior part of the shield is broad and moderately swollen, about $1.6 \mathrm{~mm}$ long. The nymph shields of the males are elongated, in some almost white, oval in shape. The sectoral part is covered with hairy filaments, the length of the shield is 1-1,2 mm, its worm skin is light yellow.

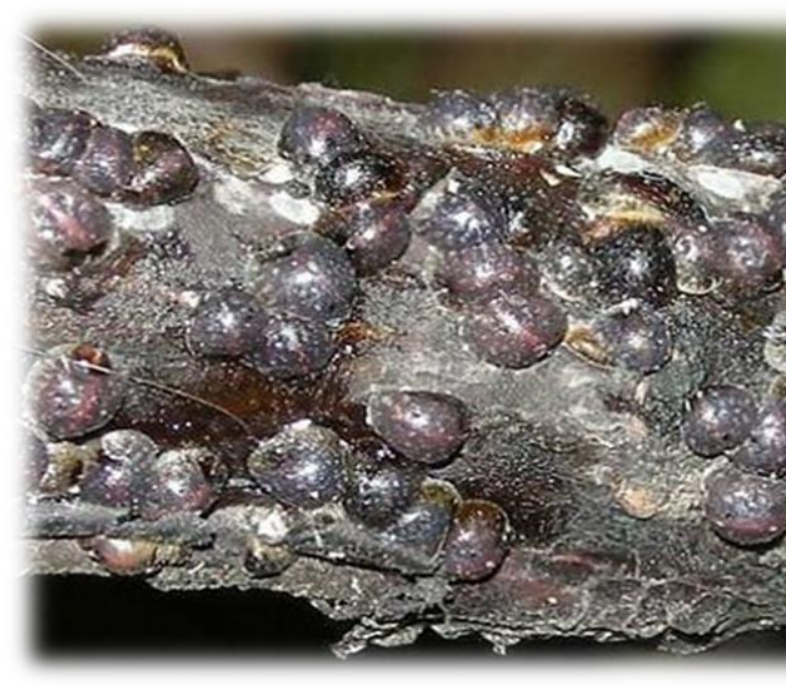

Figure 3. Plum Shield (Tecaspis asiatica

\section{Arch.)}

Infects many species of fruit trees, the females feed on apricot, cherry, plum, almond branches and twigs. Significant damage to cherries and plums. The female of the plum shield overwinters on slender twigs in the form of an imago. Gives offspring twice a year.

The Central Asian comma shield used to resemble the comma shield of an apple (Lepidosaphes ulmi Bouche). N.S. Borxsenius divided these shields into independent species. Depending on the morphological character of the Central Asian comma shield (Lepidosaphes mesasiatica Borches), then these differences are also confirmed by their biological properties.

The shield attaches to the body, twigs and branches of the cherry, especially by clumping in the leaf veins and absorbing its juice. Strongly damaged trees stunted growth, the leaves begin to fall off early, the yield decreases, the quality of the fruit deteriorates. In the farms where the observations were made, the total damage to fruit trees was $0,96 \%$, cherries were more severely damaged $-1,41 \%$; peaches $-1,14 \%$; apricots $-1,03 \%$. At the same time, the damage to the first score was $0,06 \%$; two balls $0,76 \%$; three points is $0,64 \%$. In terms of spread and damage, it ranks third after the previous two rounds.

In late April, early May, the larvae begin to emerge (larvae). Our observations show that the larvae emerge first from the eggs on the south and west sides of the tree trunk, as these sides are better heated by the sun. In 2018, the first larvae began to appear on April 27 at an average ten-day temperature of $15,8^{\circ} \mathrm{C}$, relative humidity at $69 \%$, and on May 5 , 2019 at an average temperature of $21,5^{\circ} \mathrm{C}$, relative humidity at $48 \%$. It should be noted that the emergence of "daidy" larvae coincides with the general flowering period of white acacia (Robinia pseudoacacia).

The larvae that hatch from the eggs emerge from under the mother's shield and crawl along the trunk and branches of the tree in search of food. Finding a convenient place to feed, they pierced the bark with their long hoses and asked for cell sap. Most of the larvae gather under the young twigs, being in the leaf band. But they are almost nonexistent in the leaf plate itself.

As the larva feeds, fluffy hairs appear on the surface of its body, the hairs then darken, thicken, and a shield is formed. In larvae, the larval filaments are located on the inside of the shield. In the process of hatching, the larvae lose their eyes, whiskers and legs.

The second-year larvae are in the second decade of May

(May 18), when the average daily temperature was $18,5^{\circ} \mathrm{C}$ in 2017 and the relative humidity was $63 \%$, and in the third decade of May (May 27 ) in 2018 , the average ten-day temperature 
was $20,2^{\circ} \mathrm{C}$ and the relative humidity was $50 \%$. In 2018, the first nymphs of first-generation males appeared in early June (6.VI). Male flight and adult females were detected at the end of the second decade of June (28.06.2018) and at the beginning of the third decade of June (22.06.2018). At the end of June (29.06) it was determined that the females of the first generation lay eggs.

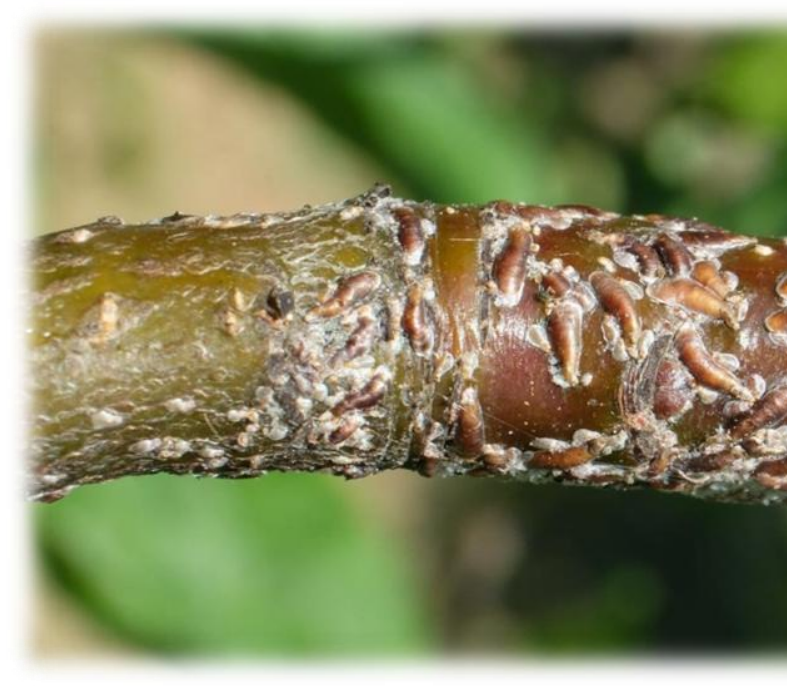

Figure 4. Central Asian comma shield

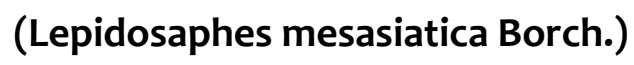

The female lays the egg under her shield, the body of the female bends during the laying of the egg and slowly moves to the head of the shield. The sexual productivity of a firstgeneration female is less than that of a second-generation female. The female of the first generation lays an average of $61,8-64,3$ eggs, while the second generation lays $84,5-$ 92,3 eggs. It should be noted that some females can lay up to 120 or more eggs. The productivity of females depends on the density of the shield.

\section{RESEARCH METHODOLOGY}

Entomological calculations and observations were performed by V.Yakhontov, A.A.Zakhvatkin, S.A.Murodov, O.T.Eshmatov; Pest accounting B.M.Adashkevich, E.S.Sheykov; Pest type G.Ya.Bey-Bienko; Pest Bioecology K.Fasolate, V.F.Pale; Pest density was carried out on the basis of Sh.T.Khojaev's methods. The degree of insect damage was determined by the method of V.I Tansky.

\section{ANALYSIS AND RESULTS}

During the observations (Tashkent region, 2018-2020), the species of shields on fruit trees were identified, including very dangerous species. These include the California shield (Quadraspidiotus perniciosus Comst.), The purple shield (Parlatoria oleae Colvee), the Central shield (Lepidosaphes mesasiatica Borch.), And the plum shield (Tecaspis asioatica Archioda). Rhodococcus turansis Arch.), Acacia false shield (Parthenolcanium corn Bouche.), Peach false shield - (Parthenolecanium persicae F.) were studied.

In apple orchards, purple shield and California shield have the highest level of damage to various shrubs, i.e. $34,4 \%$ purple shield, $30,2 \%$ California shield, $11,4 \%$ plum shield, $10,9 \%$ Central Asian shield shield, 8,9\% rose shield, while the remaining species accounted for 6,9\% (Figure 5). 


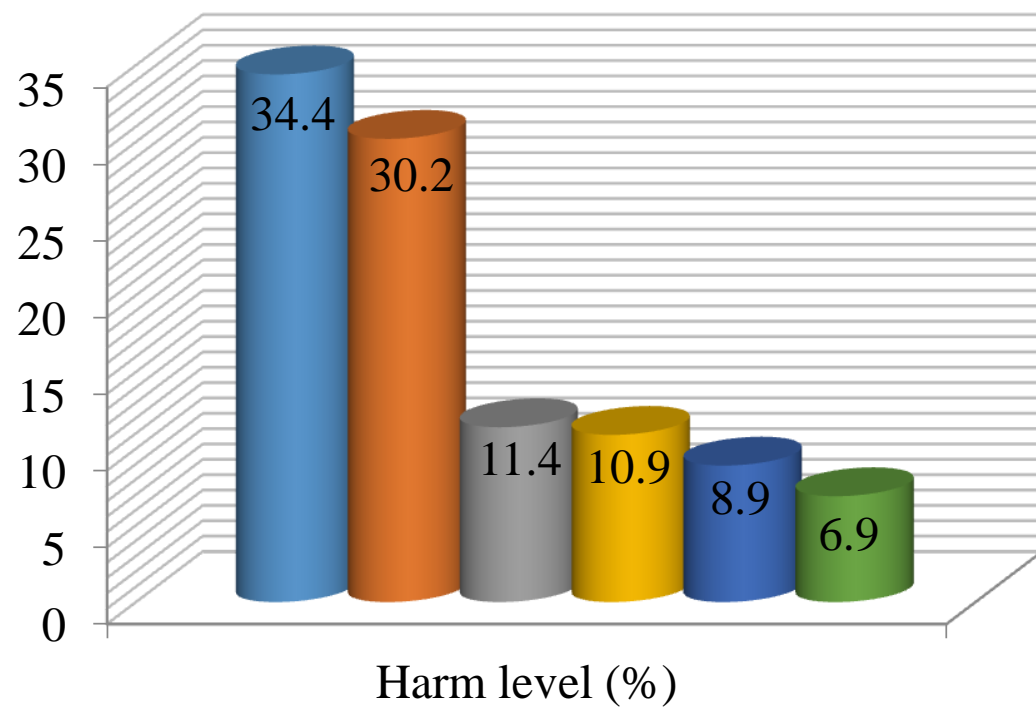

- Parlatoria oleae

Quadraspidiotus perniciosus

Chlidaspis prunorum

- Lepidosaphes mesasiatica

- Aulacaspis rosae

other types

Figure 5. Level of damage of apple trees in apple orchards (Tashkent region, 20182020).

Infestation of fruit trees with California shield (Quadraspidiotus perniciosus) affected pears and apples by $12,8 \%$, plums and apricots by
$10,1 \%$, cherries and quinces by $10,9 \%$, peaches by $9,7 \%$, and cherries by a minimum of $8,6 \%$. studied (Figure 6).

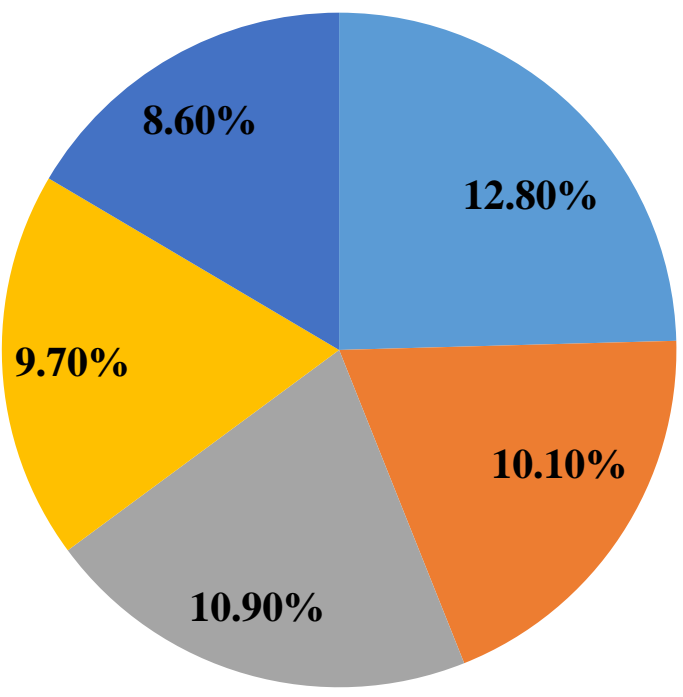

pears and apples

plums and apricots

cherry and quince

peach

cherry

Figure 6. Infestation of fruit trees with California shield (Tashkent region, 2018-2020).

\section{CONCLUSIONS AND SUGGESTIONS}

In apple orchards, purple shield and California shield have the highest levels of damage to various shrubs, with $34,4 \%$ purple shield, $30,2 \%$ California shield, $11,4 \%$ plum shield, 10,9\%
Central Asian shield shield, 8,9\% rose shield, while the remaining species accounted for $6,9 \%$.

Influence of California shield (Quadraspidiotus perniciosus) on fruit trees affected $12,8 \%$ of 
pears and apples, 10,1\% of plums and apricots, $10,9 \%$ of cherries and quinces, $9,7 \%$ of peaches and at least $8,6 \%$ of cherries.

\section{REFERENCES}

1. X.X.Kimsanbayev, B.E.Murodov, U.D.Ortikov, O.A.Sulaymonov, J.N.Yakhyoyev Bioecology, crystal pharmaceutical support and efficiency of california shield // International Journal of Research. With impact factor 5.60. - 2019. № 6. - P. 142-148.

2. B.E.Murodov, U.D.Ortikov, J.N.Yakhyoyev Bioecology of california shield (Quadraspidiotus perniciosus Comst) in Uzbekistan / Proceedings of International Multidisciplinary Scientific Conference on Innovative Technology. Organized by Novateur Publications, India. May 25th, - 2020. - P. 104-107.

3. J.N.Yakhyoyev, Kh.Kh.Kimsanbayev,

B.E.Murodov, B.A.Sulaymonov Bioecology And Phenological Development of The Californian Shield (Quadraspidiotus Perniciosus Comst.) In Uzbekistan /l The American Journal of Agriculture and Biomedical Engineering. USA. August 02, 2020 | Pages: 124-131.

4. Kh.Kh.Kimsanbaev, BE Murodov, U.D. Ortikov, OA Sulaimonov, Zh.N. Yakhoev Quarantine measures against the Californian scale insect (Quadraspidiotus perniciosus Comst) I AGROECOLOGICAL ASPECTS OF SUSTAINABLE DEVELOPMENT OF AGRICULTURE. - 2019 .-- S. 91-93.

5. Kh.Kh.Kimsanbaev, B.E.Murodov, U.D. Ortikov, A.R. Anorbaev, Zh.N. Yakhoyev Application of lacewing
6.

7.

8.

9.

10.

11.

in the fight against the Californian scale insect (Quadraspidiotus perniciosus comst.) On an apple // Actual problems modern science. - 2019. - No. 4 (107). - S. 176-178.

Kh.Kh.Kimsanbaev, B.E.Murodov, U.D. Ortikov, OA Sulaimonov, Zh.N. Yakhoyev Biological efficacy of using the drug hectolineum 5\% k.s against the Californian scale insect (Quadraspidiotus perniciosus comst.) on an apple // Actual problems of modern science. - 2019. - No. 4 (107). - S. 179-181.

Kh.Kh.Kimsanbaev, BE Murodov, U.D. Ortikov, OA Sulaimonov, Zh.N. Yakhoyev Apple pest, Californian scale insect (Quadraspidiotus perniciosus Comst.) And the use of the drug Entomin KE. against it // Actual problems of modern science. 2020. - No. 1 (110). - S. 105-107.

BE Murodov, U. A. Masharipov, Zh.N. Yakhoev Californian scale insect - Quadraspidiotu sperniciosus Comst // Education and Science in Russia and Abroad. - 2017. - No. 1 (30). -FROM. 21-23.

BE Murodov, Zh.N. Yakhoyev Quarantine pests of internal quarantine of the Republic of Uzbekistan // Education and science in Russia and abroad. 2017. - No. 3 (32). -FROM. 32-36.

BE Murodov, OA Sulaimonov, Zh.N. Yakhoev California scale insect on an apple // Education and science in Russia and abroad. - 2018. - No. 12 (47). - S. 118-122.

BE Murodov, UD Ortikov, Zh.N. Yakhoev Bioecology and development of the Californian scale insect (Quadraspidiotus perniciosus Comst.) In Uzbekistan /I EURASIAN UNION OF 
SCIENTISTS (ESU). - 2020. - 5 (74).

- S. 39-40.

12. U.D. Ortikov, Zh.N. Yakhoev, Kh.Kh. Pardaev Dangerous coccid. Californian scale insect (Quadraspidiotus perniciosus Comst) // Education and Science in Russia and Abroad. - 2018. - No. 6 (41). - S. 105-107.

13. Zh.N. Yakhoev, Kh.Kh.Kimsanbaev, BE Murodov, OA Sulaimonov, Development of the Californian scale insect in Uzbekistan // Education and science in Russia and abroad. 2018. - No. 16. - S. 225-228.

14. Zh.N. Yakhoev, Kh.Kh. Kimsanbaev, BE Murodov // Quarantine measures against the Californian scale insect (quadraspidiotu sperniciosus comst) - Young scientist. - 2020. No. 32 (322). - S. 63-66. 